\title{
Looking on Policy and Social Policy in the Context of Public Administration and Management
}

\author{
Farhad Nezhad Haj Ali Irani (Corresponding Author) \\ Public Management, $\mathrm{PhD}$ \\ Islamic Azad University, Bonab Branch, Iran
}

Tel: 98- 0412-7238893-5, Fax: 98- 0412-7238894,Email: F_NejadHajiAliIrani@yahoo.com

\author{
Mohammad Reza Noruzi, EMBA, PhD Student \\ Policy Making in Public Sector \\ Islamic Azad University, Bonab Branch, Iran \\ Young Researchers Club Member, Islamic Azad University, Bonab Branch, Iran \\ Tell: +98-412-7238893-5, mr.noruzi@modares.ac.ir,mr.noruzi.pnu@gmail.com
}

Received: June 11, 2011 Accepted: June 15, $2011 \quad$ DOI: 10.5296/jpag.v1i1.712

\begin{abstract}
The role of policy is important in economic, social and political related issues. The search for coordination and coherence of policies should take into account the fact that ideas about policy and its role in development have changed over time, indicating the difficulty to find clarity on the approaches to social investment, poverty alleviation and equity. This paper aims to study the importance of the policy, social policy and its related materials.
\end{abstract}

Keywords: Policy, Social policy, policy process 


\section{Introduction}

A poor understanding of why and how social policy is not subject developed fine detail, is the traditional concern of social policy count of people with their own facts against the interests of sociologists and political scientists in the broad sense of events or theory, which is not to say that there is a truth that everyone can agree. The history of social policy is as contested as any other. But if the claim is that the welfare development illustrates the limitations of modernist exercise, may be more helpful to recognize the various and different ways that welfare has taken. Moreover, the history and development of social policy now illuminates the modernity and reveals greater complexity and ambiguity of what is often thought.

The first reason for wanting to get involved in social policy debate in the transitional period has to be a response to the clamor made by the future of welfare by social thinkers. However, analytical recounting of the many views on social policies that have been expressed in scientific publications, such as the Social Policy Journal concluded that tend to reflect the position of taxpayers and perhaps points Given some of the collective editors, but the search for a simple consistent approach would be a futile task (Wikipedia, 2011).

Political structures of nation states as a major challenge facing political and social institutions to design formulate and implement social policies that promote economic growth and social development under conditions of fiscal constraints and requirements that limit the room for maneuver. The institutional design of the welfare state supports the implementation of social policy to mitigate the excesses of liberal capitalism. The design of the welfare state, as also known, is an ideological construct, political and social action is based on the exercise of state power the formulation and implementation of social policies (Wikipedia, 2011).

Today we are experiencing good improvements in policy, social policy and policy making. A lot of good researches have been done on these issues and helped for the development of policy and these shows the importance of these issues.

Policies are operating rules that can be referred to as a way to maintain order, security, consistency, or otherwise force a goal or mission. For example, a town council might have a policy against hiring the relatives of council members for civic positions. Each time that situation arises; council members can refer to the policy, rather than having to make decisions on a case-by-case basis (policy-based management, 2011).

There is fertile ground for considering the welfare states and social policy as essentially modern and diametrically opposed to all things postmodern. Although there are deep holes in many of the counts being used by post-classical observers and frustrating to treat rejection of social policy as seriously as they claim for their own work as in the case of postmodern approaches, there are aspects that are compatible with the criticisms of the approach of critical social policy. If one accepts what is being put on the agenda, who wants to get involved with academics familiar with the details of social policies from these perspectives, it is possible to accept his account of the developments closely and recognize well the points rose about need to fundamentally rethink everything (Wikipedia, 2011).

A "policy" is very much like a decision or a set of decisions, and we "make", "implement" or

"carry out" a policy just as we do with decisions. Like a decision a policy is not itself a statement, nor is it only a set of actions, although, as with decisions, we can infer what a 
person's or organization's policy is either from the statement he makes about it, or, if he makes no statement or we don't believe his statement from the way he acts. But, equally, we can claim that a statement or set of actions is misleading and does not faithfully reflect the "true" policy. In some other ways a policy is not like a decision. The term policy usually implies some long-term purpose in a broad subject field (e.g. land tenure), not a series of ad-hoc judgments in unrelated fields. Sometimes, however, we conceive of policy not so much as actively purpose oriented but rather as a fairly cohesive set of responses to a problem that has arisen. In the sphere of government development activities, governments have policies, plans, programmers and projects, each of these in succession being a little more short-term, more specific in place and timing than the previous and each successively more executive rather than legislative (FAO, 2008).

\section{Social Policy Implementation}

Social policy will help the community much more improvement in different aspects for example some come in the following:

- Quality of life

- Education

- Citizenship

- Culture

- Income

- Economic

- Resident in the rural areas (Irani \& Noruzi, 2011)

The result of the implementation of social policies that have gone through profound changes in its design is alarming in terms of deep social inequalities and the welfare of individuals in society.

Societies are 'structured' in the sense that people's relationships follow consistent patterns. Fiona Williams has argued that social policy is dominated in practice by the dominant values of society - the issues of family, work and nation.

Family A range of policies are built around the idea of the 'family' as a man, woman and children. Examples are child benefits, education and child care. Some countries have policies built on the idea of the man as 'breadwinner', with support based on the idea that the marriage is permanent and the woman will not work. Families which deviate from the norm - for example, poor single mothers - are likely to be penalized, though there may also be anomalies in the organization of benefits (e.g, when promiscuity is accepted and stable cohabitation is not).

Work Many systems of social protection depend on a stable work record for basic cover in 
unemployment, ill health and old age. Workers who misbehave - for example, by striking or being dismissed - may be penalized.

Nation Most systems discriminate against non-citizens, and many have residence rules for particular benefits or services. Immigrants are likely to have different, and often second-class, services.

These issues are discussed further in the sections which follow (William, 1988: Spicker, 2000).

Thus, social policy is that part of public policy that has to do with social issues. The Malcolm Wiener Center for Social Policy at Harvard University describes it as "public policy and practice in the areas of health care, human services, criminal justice, inequality, education, and labor." (Rittel \& Webber, 1973). Social policy often deals with issues which Rittle \& Webber (1973) called wicked problems.

\section{Effective Policy Making}

There are different approaches in management especially in today's turbulent ongoing days. Because environment changes a lot so policies and policy making strategies always changes and becoming more complicated and sophisticated. Now policy-based management is one of these strategies. Policy-based management is an administrative approach that is used to simplify the management of a given endeavor by establishing policies to deal with situations that are likely to occur.

According to the Strategic Policy Making Team Cabinet Office (1999), an effective policy making has lots of competencies for organizations below are some of them:

- Creating the map of success and forward looking - takes a long term view, based on statistical trends and information;

- Finding future opportunities;

- Finding the failures;

- Overall and outward looking- takes account of factors in the national, European and international situation and communicates policy effectively;

- Evaluating the process road and Predictions, of the likely impact of policy and builds systematic evaluation of early outcomes into the policy process;

- Mapping creativity in the organization and Innovative and creative - questions established ways of dealing with things and encourages new ideas; open to comments and suggestions of others;

- Finding and evaluating different forces, public, private and political forces;

- Minimizing the policy failure; 
- Using evidence - uses best available evidence from a wide range of sources and involves key stakeholders at an early stage;

- Inclusive - takes account of the impact on the needs of all those directly or indirectly affected by the policy;

- Coalition and Joined up - looks beyond institutional boundaries to the Government's strategic objectives; establishes the ethical and legal base for policy;

- Evaluating feedback - keeps established policy under review to ensure it continues to deal with the problems it was designed to tackle, taking account of associated effects elsewhere

- Learning lessons - learns from experience of what works and what doesn’t (Noruzi \&, Hernandez 2010).

\section{Social Policy and Administration}

Social Policy and Administration is an academic subject concerned with the study of social services and the welfare state. It developed in the early part of the 20th century as a complement to social work studies, aimed at people who would be professionally involved in the administration of welfare. In the course of the last forty years, the range and breadth of the subject has developed. The principal areas relate to

- policy and administrative practice in social services, including health administration, social security, education, employment services, community care and housing management;

- social problems, including crime, disability, unemployment, mental health, learning disability, and old age;

- issues relating to social disadvantage, including race, gender and poverty; and

- the range of collective social responses to these conditions.

Social Policy is a subject area, not a discipline; it borrows from other social science disciplines in order to develop study in the area. The contributory disciplines include sociology, social work, psychology, economics, political science, management, history, philosophy and law (Spicker, 2007).

\section{Iran, Islam and History of Social Policy}

Islamic republic of Iran is an Islamic country which has a good and comprehensive policy making system with its base and foundation on holy Quran and Islamic roles.

Evidence suggesting that policy and policy making is one of the fundamental parts of any government. And there are different types of policy making process in different countries, for 
example some countries having democratic and some have dictatorship policy making process (Danaee Fard \& Noruzi, 2011).

Islam is one of the most important proponents of social policy Muslims were always pioneer in helping and giving money for the poor to have good life as the other and the earliest example goes back to Umar ibn al-Khattāb's rule as the second caliph of Islam. He used zakah collections although it is now be used and a lot of Muslim countries use it and also other governmental resources to establish pensions, income support, child benefits, various stipends for people of the non-Muslim community. In the West, proponents of scientific social planning, such as the sociologist Auguste Comte, and social researchers, such as Charles Booth, contributed to the emergence of social policy in the first industrialized countries. Other significant examples in the development social policy are the Bismarckian welfare state in 19th century Germany; social security policies introduced by the New Deal in the United States between 1933 and 1935, and health reforms in the UK following the Beveridge Report of 1942 (social policy, 2006).

Modern government is based on a social contract between citizens and the state in which rights and duties are agreed to by all to further the common interest. Citizens lend their support to a government through taxes and efforts to a country's good; in return, governments acquire legitimacy by protecting the people's rights and through public policies that benefit all. However, policy making is often captured by powerful groups and elites, making government policies biased and unaccountable to the majority of citizens. With half the world's population living below the two-dollar -aday poverty line, ineffective social policies can be the spark for state breakdown (Ortiz, 2007, p. 7).

\section{Policy and Management}

Policy plays an important role within the University. It provides the principles which dictate how the members of the University will act.

The variables of uncertainty and ambiguity are often associated with some post-classical approaches to social policy that seem to pervert. Moreover, risk and risk assessment are central to contemporary welfare state to involve both critical approaches, and to the more orthodox social policy, pointing to the pensions which are a good example to illustrate the elements of exclusion and notions of risk-based insurance and their inherent limitations for much of the design schemes of social policy. But more than any essential contradiction, it is argued that we need a more informed dialogue and proud, to ensure a frank exchange of ideas on some initial clarification of the major social policy issues.

Those principles are derived from and shaped by: the law and regulations that govern the University; national standards and community expectations, and the values and mission the University articulates in its strategic plan.

\section{Results and discussions}

The contributions of university professors, politicians and elites cannot be considered low. The academic papers are deployed to offer from the major theoretical and methodological approaches and empirical research. To put in their proper context the important contributions of the processes of social policy change in the construction of social development should make some notes theoretical and methodological research into social policy. 
Policy is very important for us and we should note for this important that policy causes different goals be integrated and this integrations causes government' success.

Countries which do not from systematic policy making processes they will not be more success. They do not really know where they want to go. Policy is just like a bulb in the dark it is lightened the way the country wants to go. Also policy helps country in designing the long term planning.

Although very long term policies today are not possible because of the very fast environmental changes but this not means omitting the policy making.

More elaborate definition: Social policy relates to guidelines for the changing, maintenance or creation of living conditions that are conducive to human welfare. Thus social policy is that part of public policy that has to do with social issues such as public access to social programs. Social policy aims to improve human welfare and to meet human needs for education, health, housing and social security. In an academic environment, social policy refers to the study of the welfare state and the range of responses to social need (answers, 2011).

It is the role of Policy to:

- translate values into operations;

- ensure compliance with legal and statutory responsibilities;

- guide the University towards the achievement of its strategic plan;

- $\quad$ set standards; and

- Improve the management of risk (policy library, 2011).

Individuals and groups often attempt to shape public policy through education, advocacy, or mobilization of interest groups. Shaping public policy is obviously different in Western-style democracies than in other forms of government. But it is reasonable to assume that the process always involves efforts by competing interest groups to influence policy makers in their favor (Kilpatrick, 2000).

- It is concerned, in part, with the social policies that governments have in relation to such things as social security, health, education, housing and the personal social services. In the developed countries of the world, the scale of spending on social policies is absolutely massive and generally accounts for a major slice of national income.

- It is both multi- and inter-disciplinary. It is not, however, a subject for butterflies who flit aimlessly from idea to idea - but for magpies, who purposefully, but imaginatively, pick what they need from across the social sciences in a way that is both pragmatic and creative.

- It focuses on the nature of human interdependency; on the way in which people care for and about each other; on the part the 'welfare state' plays in shaping the nature of caring - and, for example, the gender implications; on ethical questions about principles of care and justice. 


\section{Macrothink Institute ${ }^{\text {TM }}$}

- Its goal is to maximize people's chances of a good life. Its substance, therefore, lies in the theoretical debate and practical definition of what constitutes the good life and the fundamental nature of human need (dean sample, 2005).

\section{About the Authors:}

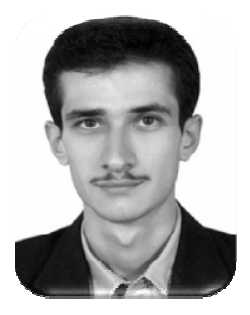

Mohammad Reza Noruzi is a PhD student of public sector policy making in Tarbiat Modarres University in Tehran, Iran. Also is an Executive Master Business Administration. He received a Master of EMBA degree with an emphasis in Strategic Management. And he received bachelor in Public Management. His ongoing research examines issues on Policy Making, Policy coordinating, Multiple Intelligence in management, globalization issues, entrepreneurship, conflicts, international business, organizational Behavior, HRM in domestic and globalization sphere and global staffing challenges. He also teaches policy making in Payam e Noor University in Iran. He has published lots of papers in national and International conferences and congresses and has conducted some research projects.

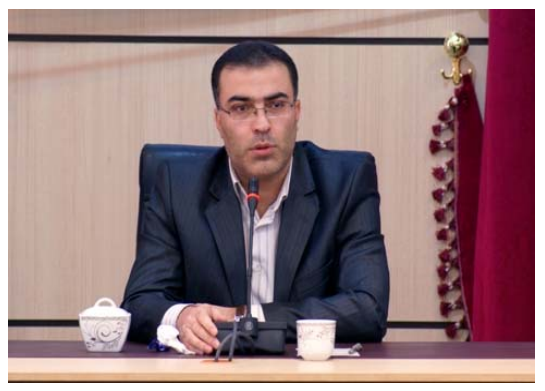

- Farhad Nezad Haj Ali Irani is a PhD in public Management. He has guided different students in master degree in public management as advisor and consulter. He has published different books in management area. He is also as a chancellor in Islamic Azad University of Bonab, Iran

\section{References}

Answers. (2011). Define social policy, answers.com available at: http://wiki.answers.com/Q/Define_social_policy.

Fard D, Noruzi N. (2011). Policy and Policy making in Iran: Issues and process, 6th edition of the International Conference on European Integration - Realities and Perspectives , Galati, Romania, on May 13th - 14th, 2011. (Forthcoming).

Dean sample. (2005). policy, available at:

http://www.polity.co.uk/shortintroductions/samples/dean-sample.pdf

FAO. (2008). Corporate Document Repository, available at:

http://www.fao.org/documents/en/detail/18573

Farhad N, Noruzi. (2011). What is policy? A brief study on policy and social policy; meanings and contents, Res Manageria, May issue (forthcoming)

Kilpatrick, Dean G. (2000). Definitions of Public Policy and the Law, National Violence against Women Prevention Research Center. 
Noruzi M, Jose G. (2010). A Short Note on the Effective Policy Making Strategies in the Public Sector Organizations. Interdisciplinary journal of contemporary research in business, August, Vol. 2. No. 4 (2010). pp. 382-387.

Ortiz, Isabel. (2007). Social Policy, National Development Strategies Policy Notes, United Nations Department For Economic And Social Affairs (Undesa).

Policy based- management. (2011). what is .com available on line at: http://whatis.techtarget.com/definition/0,,sid9_gci537241,00.html

Policy library. (2011). what is policy making role available online at: http://www.newcastle.edu.au/service/policy/definition.html Rittel, H. \& Webber, M. (1973). Dilemmas in a General Theory of Planning. Policy Sci 4:155-169.

Spicker, Paul. (2000). An introduction to Social Policy, welfare and society, available at: http://www2.rgu.ac.uk/publicpolicy/introduction/society.htm

Social Policy. (2006). available at: http://en.wikipedia.org/wiki/Social_policy Strategic Policy Making Team Cabinet Office (1999). Professional Policy Making for the Twenty First Century. 